\title{
In leprosy the presence of mycobacteria in the nerve is an essential factor in the cycle and spectrum of Mycobacterium leprae infection
}

\author{
YOHANNES NEGESSE, ${ }^{*}$ KASSA BEIMNET, \\ TIVADAR MIKO, ${ }^{*}$ ASSEFA WONDIMUS $\dagger \&$ \\ TEBEBE YEMANE BERHAN* \\ * Armauer Hansen Research Institute (AHRI), Addis Ababa, P.O. \\ Box 1005, Addis Ababa, Ethiopia; and †All Africa Leprosy \\ Rehabilitation \& Training Centre (ALERT), P.O. Box 165, Addis \\ Ababa, Ethiopia
}

\section{Accepted for publication 13 November 1992}

\begin{abstract}
Summary A total of 220 untreated leprosy patients who underwent parallel skin and nerve biopsies are included in this study, which is intended to evaluate the extent of previously reported differences in bacillary load between skin and nerve lesions in leprosy and to describe the response of peripheral blood lymphocytes to $M$ ycobacterium leprae antigens in such patients.

In 161 patients out of the 220, the skin and nerve biopsies were diagnostic for leprosy. When patients were grouped according their skin and nerve lesions, the 3 groups observed were (1) paucibacillary skin and nerve lesions; (2) multibacillary skin and nerve lesions, and (3) paucibacillary skin and multibacillary nerve lesions. There was no observation of a group of patients with multibacillary skin and paucibacillary nerve lesions. In all patients with multibacillary nerve lesions, regardless of the type of skin lesions, a low response of peripheral blood lymphocytes to $M$. leprae was consistently noted. These results suggest that the bacillary load in the nerve is certainly one of the factors determining the immunological spectrum observed in leprosy.
\end{abstract}

\section{Introduction}

Leprosy manifests itself as a spectrum from lepromatous to tuberculoid forms and affects skin and nerve. The number, distribution, appearance and bacillary load of the skin lesions are used as the main criteria for the classification of the disease. Tuberculoid patients have few skin lesions, in which $M$. leprae are rare (paucibacillary), while lepromatous patients generally have numerous skin lesions in which organisms are abundant (multibacillary). However, studies have shown differences between the bacillary load in the skin and nerves. ${ }^{1,2,3,4}$ Indeed there are patients who are classified as a paucibacillary case with regard to their skin lesion but who present with a high bacillary load in the nerves. 
Our work is intended to evaluate, in Ethiopian patients, the extent of the difference in bacillary load between the skin and the nerve and to describe these patients' T-cell response to $M$. leprae.

\section{Materials and methods}

\section{PATIENTS}

A total of 220 untreated leprosy patients who underwent parallel skin and nerve biopsies between January 1987 and June 1990 at ALERT are included in this study. The biopsies were perf ormed and examined at AHRI. All biopsied nerves were radial cutaneous nerves of the hand. The skin and nerve biopsies were routinely processed and sections were stained with haematoxylin \& Eosin and TRIFF reagents.

The skin lesions were classified according to the Ridley-Jopling criteria. ${ }^{5}$ The nerve lesions were classified as paucibacillary or multibacillary neuritis on the basis of the bacillary index (BI). The logarithmic scale used to determine the BI of smears was applied for tissue sections. A BI $>2$ was considered as a multibacillary case. ${ }^{6}$

\section{LYMPHOPROLIFERATIVE ASSAY (LPA)}

LPA were performed for a few patients randomly selected from each group. LPA were realized in the presence of $M$. leprae (batch numbers CD 106, provided by Dr R. J. W. Rees, N.I.M.R., Mill Hill, London; through the WHO/TDR IMMLEP project) or tuberculin purified protein derivative PPD (obtained from the Tuberculin Department, Statens Serum Institut, Copenhagen, Denmark).

The isolation and culture of mononuclear cells were performed according to the methods of Closs et al. ${ }^{7}$ and Reitan et al. ${ }^{8}$ Briefly $15 \times 10^{4}$ mononuclear cells per well were incubated in RPMI 1640 with 5\% Normal Human Serum for 6 days with $10 \mu \mathrm{g}$ of sonicated $M$. leprae or $10 \mu \mathrm{g}$ of PPD or as control $10 \mu \mathrm{g}$ phytohaemagglutinin (Sigma).

Results of LPA's are expressed as the mean count per minute (cpm) of triplicate wells and the degree proliferation induced by each antigen $(\Delta \mathrm{cpm})$ as cpm of stimulated culture minus cpm of unstimulated control cultures. Our result are expressed as $\Delta \mathrm{cpm}$ of $M$. leprae stimulated cultures/ $\Delta \mathrm{cpm}$ of PPD stimulated culture. Presentation of the results in this manner using PPD as internal reference circumvents the problem of interassay variations obtained when reporting results as absolute cpm.

Table 1. Grouping of patients

\begin{tabular}{llrr}
\hline \multicolumn{1}{c}{ Group } & \multicolumn{1}{c}{ Classification of lesions } & $\begin{array}{c}\text { No. of } \\
\text { Patients }\end{array}$ & Percent \\
\hline I & Indeterminate skin and Paucibacillary nerve (IS, PN) & 27 & $16 \cdot 7$ \\
II & Indeterminate skin and Multibacillary nerve (IS, MN) & 37 & $22 \cdot 9$ \\
III & Borderline tuberculoid skin and Paucibacillary nerve (BTS, PN) & 46 & $28 \cdot 5$ \\
IV & Borderline tuberculoid skin and Multibacillary nerve (BTS, MN) & 9 & $5 \cdot 7$ \\
V & Borderline lepromatous or Lepromatous lepromatous skin and & 42 & $26 \cdot 0$ \\
& $\quad$ Multibacillary nerve (LS, MN) & 42 & \\
\hline
\end{tabular}


Table 2. LPA Results

\begin{tabular}{llcc}
\hline Group & Type of skin and nerve lesions association & $\begin{array}{c}\text { No. of } \\
\text { patients tested } \\
\text { for LPA }\end{array}$ & $\begin{array}{c}\text { Mean } \Delta \text { cpm } \\
\text {. leprae } \pm \text { SD } \\
\Delta \text { cpm PPD }\end{array}$ \\
\hline I & Indeterminate skin paucibacillary nerve (IS, PN) & 3 & $60 \pm 1$ \\
II & Indeterminate skin multibacillary nerve (IS MN) & 4 & $5 \cdot 75 \pm 3 \cdot 1$ \\
III & BT skin paucibacillary nerve (BTS, PN) & 3 & $54 \cdot 3 \pm 5 \cdot 1$ \\
IV & BT skin multibacillary nerve (BTS, MN) & 9 & $9 \pm 3 \cdot 2$ \\
V & BL or LL skin multibacillary nerve (LS, MN) & 3 & $6 \pm 2 \cdot 7$ \\
\hline
\end{tabular}

\section{Results}

In 18 out of the 220 patients neither theskin nor the nerve was diagnostic for leprosy. In 27 patients only the skin biopsy was diagnostic for leprosy while in 14 patients the diagnosis of leprosy was made solely on the nerve biopsy.

In the remaining 161 patients both the skin and nerve biopsies were diagnostic for leprosy. The grouping of these 161 patients is presented in Table 1.

LPA results are presented in Table 2. In groups I (ISPN) and III (BTS, PN) the ratio of $\Delta \mathrm{cpm} M$. leprae/ $\Delta \mathrm{cpm}$ PPD was approximately $50 \%$ while in the other groups this ratio was less than $13 \%$.

\section{Discussion}

We found 5 types of association of skin and nerve involvement, but none were observed presenting with multibacillary skin and paucibacillary nerve lesions. This finding confirms the previous reports that describe a higher bacillary load in the nerve than in the skin in individual patients. ${ }^{2,9}$

Results of LPA are informative and a trend is apparent. Specifically, in patients presenting with multibacillary nerve lesion, regardless of the BI in the skin lesion, a low response of peripheral blood lymphocytes to $M$. leprae was consistently noted. In group V (patients who were unambiguously lepromatous cases), the low lymphocyte response to $M$. leprae was consistent with their classification. ${ }^{9,10}$ In group IV (patients who were BT with smear negative skin lesion and multibacillary nerve lesion), a low lymphocyte proliferative response was surprising as this is inconsistent with the classification based on skin lesion. As anticipated, group III (cases with paucibacillary skin and nerve lesion), displayed a substantial lymphocyte reactivity in the presence of $M$. leprae compared to group II, group IV and group V, all having in common multibacillary nerve lesion.

Bjune $^{11}$ has raised pertinent questions as to why so many BT patients have LPA response to $M$. leprae. Various reasons have been given ${ }^{11,12}$ and from our study one explanation may be added. The patients who have $\mathrm{BI}=0$ in skin lesion and who have low LPA response to $M$. leprae could be those who have a high bacillary load in their nerve lesion. The low responsiveness to $M$. leprae antigens of the patients with indeterminate 
skin lesion and multibacillary nerve lesion (group II) is similar to that in patients with primary neuritic leprosy, as reported by Nath and colleagues. ${ }^{13}$

Do the above observations deserve consideration regarding the type of multidrug therapy (MDT) to be prescribed for leprosy patients? Kaur et al. ${ }^{9}$ have raised the question 'do patients with multibacillary neural lesion require the WHO MDT multibacillary regimen for proper management?'. These authors feel that long-term MDT may not be necessary since the total bacillary count is less than 10 in patients with negative skin lesion and heavy bacterial load in the nerve. However, we do not share this opinion. At ALERT our policy is to prescribe a WHO multibacillary MDT regimen for all patients with paucibacillary skin lesion but with multibacillary nerve lesion.

The existence of leprosy patients classified as paucibacillary on the basis of their skin lesion but who should be considered as multibacillary for treatment purposes has been stressed by different authors. ${ }^{14,15}$ Reddy ${ }^{16}$ raised this issue and advocated a uniform longterm MDT regimen for all leprosy patients, regardless of classification. The abovementioned points of view and concepts may be addressed in a different way in the common condition of a leprosy control set-up where nerve biopsy facilities are not available. This approach may be based on the importance to be given to the lepromin test. Thus a patient diagnosed as presenting a paucibacillary leprosy but having a negative lepromin test would benefit from long-term MDT regimen.

The hospital-based study described in this paper examined only a limited number of patients, but allowed us to emphasize 2 main questions. First, our results suggest that the bacillary load in the nerve (paucibacillary or multibacillary) is certainly one of the factors determining the immunological spectrum of the disease; it has been observed that patients with multibacillary nerve lesion have low LPA response regardless of their BI in skin lesion. Secondly a heavy bacillary load in the nerve may act as a reservoir of bacilli which allows a relapse to occur; or this may allow the disease to continue due to insufficient treatment. ${ }^{17}$

In order to more fully answer these questions a larger prospective study in which multiple immunological parameters are to be assessed is in progress.

\section{Acknowledgements}

AHRI is financially supported by The Norwegian and Swedish Agencies for development (NORAD \& SIDA). The authors thank Drs Dominique Frommel and Kimberley McGinnis for their help and constructive discussions. The excellent technical assistance of Mrs Mulunesh Negash is gratefully appreciated.

\section{Reference}

1 Srinivasar H, Rao KS, Iyer CGS. Discrepancy in the histopathological features of leprosy lesions in the skin and peripheral nerve. Lepr India, 1982; 54: 275-86.

2 Nilsen R, Mengistu G, Reddy BB. The role of nerve biopsies in the diagnosis and management of leprosy. Lepr Rev, 1989; 60: 28-32.

3 Nilsen R, Mshana RN, Negesse Y, Mengistu G, Kana B. Immunohistochemical studies of leprous neuritis. Lepr Rev, 1986; 57: Suppl 2, 177-87.

${ }^{4}$ Yemane Berhan T, Negesse Y. Relapse rates in paucibacillary leprosy. WHO regimen versus initial classification. Abstract P. 118, VI World Congress of Dermatology: Tropical, Geographic and EcologicRio de Janeiro, April 29-May 3, 1989. 
5 Ridley DS, Jopling WH. Classification of leprosy according to immunity. A five group system. Int J Lepr, 1966; 34: 255-73.

6 Negesse Y. Leprous neuritis, classification of leprosy and multidrug therapy (letter). Int J Le pr, 1988; 56: 329 30

7 Closs O, Reitan LJ, Negassi K, Harboe M, Belehu A. Invitrostimulation of lymphocytes in leprosy patients, healthy contacts of leprosy patients and subjects not exposed to leprosy. Scand J Immunol, 1982; 16: 103-15.

${ }^{8}$ Reitan LJ, Closs O, Belehu A. In vitro lymphocyte stimulation in patients with lepromatous and borderline tuberculoid leprosy. The effect of dapsone treatment on the response to $M$. leprae antigens, PPD and nonmycobacterial stimulants. Int $J$ Lepr, 1982; 50: 455-67.

9 Kaur G, Girdhar BK, Girdhar A, Malaviya GN, Mukherjee A, Sengupta U, Desikan KV. A clinical study of neuritic leprosy patients. Int J Lepr, 1991; 59: 385-91.

10 Godal T, Mykestad B, Samuel DR, Myrvang B. Characterization of the cellular immune defect in lepromatous leprosy: a specific lack of circulating $M$. leprae reactive lymphocytes. Clin exp Imm, 1971; 9: $821-31$.

11 Bjune G. Variation of invitrolymphocyte responses to $M$. leprae antigen in borderline tuberculoid patients. Int J Lepr, 1980; 48: 30-9.

12 Bjune G, Barnetson R, StC, Ridley DS, Kronvall G. Lymphocyte transformation test in leprosy; correlation of the response with inflammation of lesions. Clin exp Imm, 1976; 25: 85-94.

13 Nathl, Narayanan RB, Sathish M, Ahuja GK, Singh R. Selective loss of $M$. leprae responsiveness of circulating lymphocytes in primary neuritic leprosy. Lepr Rev, 1981; 52: 79-89.

14 Bernardi CDV, Gerbase AC, Fereira J, Pino GD, Bakos L. Operational classification in Hansen's disease control. Abstract in Int J Lepr, 1984; 52: Suppl 1: 741.

15 Jesudasan K, Christian M. Risk of paucibacillary leprosy patients released from control relapsing with multibacillary leprosy. Int J Lepr, 1985; 53: 19-21.

16 Reddy NBB. Why classify leprosy patients into paucibacillary and multibacillary group? Lepr Rev, 1987; 58: 89

17 Stoner GL. Importance of the neural predilection of M. leprae in leprosy. Lancet, November 10, 1979; 994-6. 


\title{
Dans la lèpre, la présence de mycobactéries dans le nerf est un facteur essentiel dans le cycle et le spectre de l'infection par Mycobacterium leprae
}

\author{
Yohannes Negesse, Kassa Beimnet, Tivadar Miko, Assefa Wondimu et \\ Tebebe Yemane Berhan
}

Résumé Deux cent vingt lépreux non traités qui ont eu des biopsies parallèles de la peau et du nerf sont inclus dans cette étude qui a pour but d'évaluer l'importance des différences signalées auparavant entre la charge bacillaire des lésions cutanées et celle des lésions nerveuses dans la lèpre et de décrire la réponse des lymphocytes du sang périphérique aux antigènes de $M$. leprae chez ces patients.

Chez 161 patients sur les 220, les biopsies cutanées et nerveuses ont amenéà un diagnostic de lèpre. Lorsque les patients ont été répartis suivant leurs lésions cutanées et nerveuses, on a observé les trois groupes suivants: (1) lésions cutanées et nerveuses paucibacillaires; (2) lésions cutanées et nerveuses multibacillaires et (3) lésions cutanées paucibacillaires et lésions nerveuses multibacillaires. On n'a pas observé de groupe de patients avec des lésions cutanées multibacillaires et nerveuses paucibacillaires. Chez tous les patients portant des lésions nerveuses multibacillaires, quel que soit le type des lésions cutanées, on a constamment noté une faible réponse des lymphocytes du sang périphérique à $M$. leprae. Ces résultats suggèrent que la charge bacillaire dans le nerf est certainement un des facteurs déterminant le spectre immunologique observé dans la lèpre.

\section{En los casos de lepra, la presencia de Mycobacterium en el nervio es un factor imprescindible en el ciclo y gama de infección por Mycobacterium leprae}

\author{
Yohannes Negesse, Kassa Beimnet, Tivadar Miko, Assefa Wondimu y \\ Tebebe Yemane Berhan
}

Resumen Doscientos veinte pacientes con lepra sin tratar que fueron sometidos a biopsias en paralelo de piel y neural, participaron en este estudio cuya intención fue evaluar las diferencias informadas anteriormente de la carga bacilar entre lesiones de la piel y neural en la lepra, y describir la respuesta de los linfocitos hemáticos periféricos a los antigenos Mycobacterium leprae en tales pacientes.

En ciento sesenta y un pacientes de los doscientos, las biopsias de piel y neurales fueron positivos para la lepra. Cuando se agruparon los pacientes de acuerdo con las lesiones de piel y neurales, los tres grupos fueron (1) lesiones de piel y neural paucibacilares; (2) lesiones de piel y neural multibacilares; (3) lesiones de piel paucibacilares y neural multibacilares. No se encontró un grupo de pacientes con lesiones de piel multibacilares y neural paucibacilares. En todos los pacientes, sin tener en cuenta el tipo de lesión de la piel, se notó una respuesta ba ja de los linfocitos hemáticos periféricos de $M$. leprae. Estos resultados sugieren que ciertamente la carga bacilar de los nervios es uno de los factores que determina la gama immunológica de la lepra. 